\title{
Nitrogen and Phosphorus Recovery from Wastewater
}

\author{
Sukalyan Sengupta ${ }^{1} \cdot$ Tabish Nawaz $^{1} \cdot$ Jeffrey Beaudry $^{1}$
}

Published online: 20 August 2015

(C) Springer International Publishing AG 2015

\begin{abstract}
Use of nitrogen- and phosphorus-based synthetic fertilizers shows an increasing trend, but this has led to largescale influx of reactive nitrogen in the environment, with serious implications on human health and the environment. On the other hand, phosphorus, a non-renewable resource, faces a serious risk of depletion. Therefore, recovery and reuse of nitrogen and phosphorus is highly desirable. For nitrogen recovery, an ion exchange/adsorption-based process provides concentrated streams of reactive nitrogen. Bioelectrochemical systems efficiently and effectively recover nitrogen as $\mathrm{NH}_{3}(\mathrm{~g})$ or $\left(\mathrm{NH}_{4}\right)_{2} \mathrm{SO}_{4}$. Air stripping of ammonia from anaerobic digestate has been reported to recover 70$92 \%$ of nitrogen. Membrane separation provides recovery in the order of $99-100 \%$ with no secondary pollutant in the permeate.With regard to phosphorus $(\mathrm{P})$ removal, physical filtration and membrane processes have the potential to reduce suspended $\mathrm{P}$ to trace amounts but provide minimal dissolved P removal. Chemical precipitation can remove 80 $99 \% \mathrm{P}$ in wastewater streams and recover it in the form of fertilizer (struvite). Acid hydrolysis can convert recovered $\mathrm{P}$ into usable phosphoric acid and phosphate fertilizers. Physical-chemical adsorption and ion exchange media can reduce $\mathrm{P}$ to trace or non-detect concentrations, with minimal waste production and high reusability. Biological assimilation through constructed wetlands removes both $\mathrm{N}(83-87 \%)$ and $\mathrm{P}(70-85 \%)$ from wastewaters, with recovery in the form of
\end{abstract}

This article is part of the Topical Collection on Water Pollution

Sukalyan Sengupta

ssengupta@umassd.edu

1 Civil and Environmental Engineering Department, University of Massachusetts Dartmouth, 285 Old Westport Road, North Dartmouth, MA 02747, USA fish/animal feeds and biofuel. The paper discusses methods and important results on recovery of nitrogen and phosphorus from wastewater.

Keywords Nutrient recovery · Nitrogen recovery · Phosphorus recovery $\cdot$ Sustainability

\section{Introduction}

Nutrients found in waste streams are mostly compounds of carbon, nitrogen, and phosphorus (CNP). All of them are important for sustenance of various life forms. Nitrogen and phosphorus are essential components of cell's DNA, aminoacids, and chlorophyll. In eukaryotic cells, phosphorus is the "energy currency" of the cells in the form of adenosine triphosphate, or ATP [1]. Nitrogen and phosphorus play critical roles in plant growth and food supply. While nitrogen abundantly exists in atmosphere (78 \%) in a highly stable and nonreactive form $\mathrm{N}_{2}$ gas, its content is limited in soils. Therefore, in order to make it usable and increase its availability in soils, nitrogen is fixed in reactive forms such as amino-acids, nitrate, and ammonia.

Most naturally occurring reactive nitrogen $(6.5 \mathrm{Tg}$ (teragram) N/year in US [2] and 100-300 Tg N/year globally [3]) comes from lightning ( $2 \%)$ and biological fixation $(98 \%)$. However, natural fixing of nitrogen is insufficient to meet the food and energy demand of the rising world population [4]. Therefore, anthropogenic production of reactive nitrogen shows an increasing trend [5].

On the other hand, the problem with phosphorus in the environment is of exhaustion, since it is a non-renewable resource. The most common form of phosphorus on earth is locked in igneous and sedimentary deposits, with mining of these rocks being the most viable method of extraction. Using 
the current rates of extraction and consumption, these "readily exploitable" sources of phosphorus will be depleted within next 45-100 years, as shown in Fig. 1 [6]. Moreover, as these reserves become exhausted the quality will inevitably become more variable, leading to lower phosphorus concentrations and higher impurities [7].

The use of synthetic fertilizer shows an increasing trend of $15 \mathrm{Tg} /$ year, with developing countries contributing more to the increase [3]. Smil et al. [8] estimate that the use of nitrogenous and phosphorus fertilizers has made a difference between malnutrition and adequate diet for nearly one-third of humanity. Evidently, use of nitrogenous and phosphorusbased fertilizers is critical to fight world hunger. However, only $4 \mathrm{Tg}$ of reactive nitrogen (out of $170 \mathrm{Tg}$ applied annually) actually accumulates in crop and the rest is lost through air and water pathways [8], impacting human health, bio-diversity, and air and water quality $[3,9]$. Two percent of global reactive nitrogen introduced annually escapes as $\mathrm{N}_{2} \mathrm{O}$ and contributes to global warming and affects the ozone layer [9] and $12 \%$ escapes as $\mathrm{NO}_{x}$ and $\mathrm{NH}_{3}$, affecting the atmosphere in numerous ways [10]. Additionally, resulting climate change and nitrogen interactions may also affect agricultural productivity by exposing crops to elevated $\mathrm{O}_{3}$ levels [11], flooding and extreme precipitation, drought, and heat. Moreover, phosphorus discharge, even in concentrations, as low as $0.02 \mathrm{mg} / \mathrm{l}$ can induce eutrophication of rivers and lakes, making them bogs that are unfit for navigation, fresh water supply, recreation, or agriculture [12, 13]. Ever increasing large fertilizer production may not be able to fully meet the food demand unless nitrogen and phosphorus are managed judiciously.

Since a large fraction of the synthetic fertilizer production escapes into the atmosphere [8], recovery of lost nutrient holds promise in mitigating this problem. It works on the principle of 3R's: reduce, reuse, and recycle. Nutrient recovery, therefore, reduces the burden on reactive nitrogen and phosphorus production, which in turn would ensure less reactive nitrogen and phosphorus entry into the environment. This would lead to efficient use of nutrient and cause less adverse effect on the environment. Nutrient recovery would re-introduce recovered nitrogen and phosphorus as fertilizer and drop its price and thus the overall food cost. Apart from tangible economic benefits, it would also reduce the nitrogen and phosphorus loading in the atmosphere, leading to a cleaner and greener environment [14].

The objective of this review is to study and compile the methods used for nitrogen and phosphorus recovery from wastewater. The work outlines the theoretical mechanism and concepts and recent innovations and results of each method. The review covers methods based on physical, chemical, and biological principles.

\section{Methods of Nitrogen Recovery}

\section{Ion Exchange and Adsorption-Based Methods}

Reactive nitrogen exists as $\mathrm{NH}_{4}{ }^{+}$at typical wastewater $\mathrm{pH}$ values [15]. It is also a significant contaminant in domestic grey water and urine [16]. Because it is a cation, ion exchange and adsorption-based processes are highly relevant because of their unique properties such as high selectivity for $\mathrm{NH}_{4}{ }^{+}$, high removal, fast uptake kinetics and regeneration [17-20], less space requirements and simplicity of application and operation [21], being environmental friendly [22] as it uses naturally occurring and easy-to-modify ion-exchanger/adsorbent such as zeolite [23•], and releases non-toxic exchangeable cations $\left(\mathrm{Na}^{+}, \mathrm{K}^{+}, \mathrm{Ca}^{2+}\right.$, and $\left.\mathrm{Mg}^{2+}\right)$. The most popular ion exchanger/adsorbent for nitrogen recovery is zeolite. Natural zeolites have a tetrahedral framework where aluminum and silicon atoms are covalently bonded to common oxygen atoms forming interconnected cages and channels [22]. Substitution of each $\mathrm{Si}^{4+}$ with $\mathrm{Al}^{3+}$ causes a net negative charge on the framework. These substitutions are termed isomorphous as small sized atoms occupy sites previously occupied by larger atoms. The greater the substitution, the higher the negative charge on the zeolite. These negative charges within the pores are balanced by charged cations such as $\mathrm{Na}^{+}, \mathrm{K}^{+}, \mathrm{Ca}^{2+}$, and $\mathrm{Mg}^{2+}$ on the zeolite surface. These cations are held by weaker electrostatic forces and are exchanged with $\mathrm{NH}_{4}{ }^{+}$in the solution. There are more than 50 kinds of naturally occurring
Fig. 1 Estimated global phosphorus reserves (Source: Duley, 1998 [6])

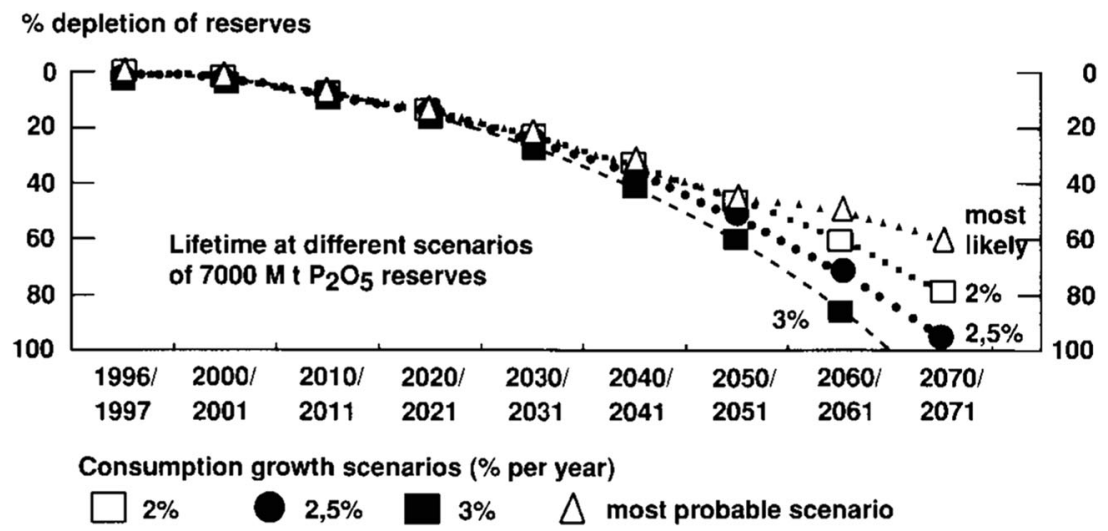


zeolites [24] which occur at different places and have different characteristics $[25,26]$. These differences in characteristics are attributed to variations in the regional geological formation [18]. Therefore, each zeolite has to be studied and modified individually to determine its optimum performance [26]. Performance of zeolites has been studied from the perspective of their homoionic forms, grain size, $\mathrm{pH}$, influent $\mathrm{NH}_{4}{ }^{+}$concentration, hydraulic retention time, ionic strength- competition with respect to other cations, and temperature $[18,19,26]$. Modification improves adsorption capacity and purity of zeolites. Treatment with acids, alkali and salts of alkaline metals, integrated calcinations, and microwave treatment are some of the popular modification techniques [23•, 26, 34•].

Once adsorbents/ion-exchangers are exhausted, nitrogen recovery and reuse opportunities are exploited. The loaded zeolites can be applied directly onto agricultural fields as slow-release fertilizers [26]. Most popular is the regeneration technique using $\mathrm{NaCl}$ solution $[23 \cdot, 26]$ where $\mathrm{NH}_{4}{ }^{+}$is desorbed and exchanged with $\mathrm{Na}^{+}$in solution. This provides a concentrated stream of $\mathrm{NH}_{4}^{+}[18,20]$. Other regeneration techniques such as acid regeneration [20], heating regeneration (particularly useful for exothermic adsorption process) [23•], and biological regeneration [27] can also be used, depending on the recovery process employed subsequently [20]. The regeneration step results in concentrated stream of $\mathrm{NH}_{4} \mathrm{Cl}$ in chemical regeneration $[19,25]$ or $\mathrm{NaNO}_{3}$ in biological regeneration $[27,28]$. The concentrated regenerant solution, after raising its $\mathrm{pH}$ above 9.3 (pKa of $\mathrm{NH}_{4}^{+}-\mathrm{NH}_{3}$ system), can be air stripped of its ammonia content, and the brine solution can be recovered. The $\mathrm{NH}_{3}$ gas can be further sorbed into $\mathrm{H}_{2} \mathrm{SO}_{4}$ solution [29] or $\mathrm{HNO}_{3}$ solution [30]. Liberti et al. [29] reported that the $\mathrm{NH}_{3}$-sorbed $\mathrm{H}_{2} \mathrm{SO}_{4}$ solution could be used as a fertilizer. The nitrate-rich solution obtained after biological regeneration can also be used as a fertilizer [28]. Liberti et al. [31] proposed a combined anion and cation exchange scheme where both ammonium and phosphate ions were concentrated and then precipitated as magnesium ammonium phosphate also known as struvite, a known slow-release fertilizer. Karapinar [17] utilized ammonium-loaded zeolite as a seeding material for precipitating calcium phosphate and suggested the possibility of using the precipitate-ammoniumloaded zeolites as fertilizer. Lind et al. [32] used saturated clinoptililolite, wollastonite, and a natural zeolite and a small amount of $\mathrm{MgO}$ to recover nitrogen (65-80\% recovery) as struvite and as adsorbed crystalline $\mathrm{NH}_{4}{ }^{+}$on the zeolites. Lin et al. [33] proposed a two-step scheme where $\mathrm{NH}_{4}{ }^{+}$adsorption to a zeolite released $\mathrm{Ca}^{2+}$ ions to solution which formed the precipitate of calcium phosphate. Additionally, the used zeolite can be used as green fertilizer. Huang et al. [34•] used $\mathrm{MgCl}_{2}$-modified zeolite to simultaneously precipitate ammonium and phosphate ions as struvite utilizing the $\mathrm{Mg}^{2+}$-loaded zeolite as the magnesium source. Recently, some novel adsorbents, such as carbon nanotubes [35], hydrogels [36], and natural substances such as wheat straw and volcanic tuff, [37] have been reported for ammonium removal. Wang et al. [38] synthesized palygorskite nanocomposite which exhibited excellent adsorption capacity of $237.7 \mathrm{mg} / \mathrm{g}$ and was reused as a slow-release fertilizer. Zheng et al. [39] reported the use of chitosan-g-poly(acrylic acid)/attapulgite (CTS-g-PAA/APT) hydrogels prepared by in situ co-polymerization in aqueous solution. It showed an adsorption capacity of $21 \mathrm{mg} / \mathrm{g}$. The $\mathrm{NH}_{4}{ }^{+}$-loaded hydrogel, with its unique water retention characteristics and multi-functionality, can be used as a fertilizer in agriculture. Wheat straw as adsorbents have received much focus recently [40, 41]. Wheat straw has a high ammonium uptake capacity of $148.7 \mathrm{mg} / \mathrm{g}$ [40]. Liu et al. [41] prepared super adsorbent resin (SAR) from wheat straw, optimized its performance, and suggested its use as a slow-release fertilizer. Jellali et al. [42] reported the use of another natural biodegradable waste Posidonia oceanica (P. oceanica) for ammonium recovery and suggested its possible use as bio-compost in agriculture. Wahab et al. [43] used sawdust to recover ammonium ions from the wastewater and suggested the use of ammonium-loaded sawdust as bio-compost and fertilizers.

\section{Bioelectrochemical Systems (BES)}

In BES, chemical energy contained in the organic matter is directly converted to electrical energy by certain microorganisms. Bio-oxidation of organic matter generates electrons and simultaneously produces other valuable compounds. At the anode, anaerobic bacteria oxidize the organic matter, often represented by the oxidation of acetate [44]:

$$
\mathrm{CH}_{3} \mathrm{COO}^{-}+4 \mathrm{H}_{2} \mathrm{O} \rightarrow 2 \mathrm{HCO}_{3}^{-}+9 \mathrm{H}^{+}+8 \mathrm{e}^{-}
$$

Microorganisms transfer these generated electrons to anode, which is connected over an external circuit to cathode - the site of reduction reaction. Based on the cathodic reaction, BESs can be classified into two types: galvanic and electrolytic cells. Galvanic cells are microbial fuel cells (MFCs) which produce electricity by coupling the anodic oxidation to the reduction of an electron acceptor [45]. In electrolytic cells, typically called microbial electrolysis cell (MES), electricity is needed to carry out the reduction reaction at the cathode and anodic oxidation is coupled to reduction of protons to hydrogen gas [46, 47]. The cathodic reaction of an MFC is oxygen reduction reaction (ORR) and for MEC is hydrogen evolution reaction (HER). At near neutral or alkaline $\mathrm{pH}$, the reaction can be written respectively as:

$$
\begin{aligned}
& 2 \mathrm{H}_{2} \mathrm{O}+\mathrm{O}_{2}+4 \mathrm{e}^{-} \rightarrow 4 \mathrm{OH}^{-} \\
& 2 \mathrm{H}_{2} \mathrm{O}+2 \mathrm{e}^{-} \rightarrow \mathrm{H}_{2}+2 \mathrm{OH}^{-}
\end{aligned}
$$

Anode and cathode chambers are separated by an ion exchange membrane to prevent mixing of the oxidation and reduction products $[46,48]$. The ion exchange membrane 
maintains electro-neutrality by allowing anions and/or cations to pass through.

BES scheme is potentially a sustainable way of treating wastewater as it produces electricity and recovers ammonia and utilizes low-grade substrates such as wastewater itself as an electron source, thus reducing the use of carbon source. However, present energy recovery is too low [49]. Therefore, low energy recovery and requirements (due to reduced aeration) make it more suitable for contaminant removal and resource recovery.

In the case of ammonium recovery, the organic matter in wastewater is oxidized at the anode by bacteria, while ammonium ions are transported over a cation exchange membrane to the cathode chamber [50• ], where the high $\mathrm{pH}$ allows for recovery as ammonia. BES systems do not need addition of a strong base as compared to other ammonia recovery technologies. Kuntke et al. [51・•] successfully recovered ammonia from urine through volatilization due to high $\mathrm{pH}$ of the cathode chamber and aeration and subsequent absorption in an acid solution in an MFC. Desloover et al. [52] recovered ammonia from anaerobic digestate using an MEC, where ammonia transported across a membrane in the cathode was stripped by the produced hydrogen gas with much lower energy demand than the conventional stripping. Haddadi et al. [53] established that higher current density would greatly enhance the ammonia recovery in an MFC as $61 \%$ of ammonia transport is electricity driven. Wu and Modin [54] using an MEC achieved simultaneous hydrogen production and ammonia recovery ( $96 \%$ from synthetic wastewater and $79 \%$ from real wastewater) by manipulating the catholyte $\mathrm{pH}$ to 12 obtained due to current generation.

BES schemes are new and need optimization of various parameters. Ammonia recovery greatly depends upon current density, catholyte $\mathrm{pH}$, concentration of ammonium ions in the waste stream, type of membrane, and equilibrium among ions. These parameters are inter-related, e.g., current density determines catholyte $\mathrm{pH}$ which in turn is affected by type of membrane and ions in the solution [55]. Janicek et al. [56] conclude that pilot studies are essential to show the practical feasibility of BES. No full-scale applications of BES technologies have been reported so far. In 2013, Wetsus has set up a pilot plant at the water board of Fryslân, Leeuwarden, The Netherlands.

\section{Air Stripping of Ammonia}

Air stripping of ammonia has been in use for nitrogen removal [57]. It is a pH-dependent scheme where at $\mathrm{pH}$ around 9.3, ammonium nitrogen from solution converts to ammonia gas. Therefore, in the process, lime or caustic soda is usually applied to keep the $\mathrm{pH}$ around 10.8-11.5. This converts ammonium ions to ammonia in solution, and simultaneous air supply converts it to ammonia gas and strips ammonia according to the following reaction [58]:
$\mathrm{NH}_{4}{ }^{+}+\mathrm{OH}_{\rightarrow}^{- \text {air }} \mathrm{H}_{2} \mathrm{O}+\mathrm{NH}_{3}(\mathrm{~g})$

For high stripping efficiency, the process is carried out in a packed tower, as it provides large mass transfer area. The process is affected by various factors such as ammonium concentration of feed, hydraulic loading, air flow rate, packing, etc., but most important are $\mathrm{pH}$ and temperature [59-61]. Guo et al. [59] reported increased ammonia recovery efficiency from 80 to $92 \%$ on $\mathrm{pH}$ increase of $8-11$. Gustin and Marinsck-Lograb [58] noted $27 \%$ recovery efficiency at $\mathrm{pH} 8.5$ but it rapidly rose to $92 \%$ as the $\mathrm{pH}$ changed to 11 . Several studies established a $\mathrm{pH}$ value of 11-12 for economically optimum recovery [60, 61]. Gustin and MarinsckLograb [58] reported a $\mathrm{pH}$ of 10.5 at temperature of $50{ }^{\circ} \mathrm{C}$. Bonmati and Flotats [62] obtained $87 \%$ recovery at a $\mathrm{pH}$ of 9.5 and a temperature of $80^{\circ} \mathrm{C}$; they also concluded that the air stripping is independent of $\mathrm{pH}$ at temperature greater than $80{ }^{\circ} \mathrm{C}$. Katehis et al. [63] obtained a temperature value of $75^{\circ} \mathrm{C}$ at which the process becomes $\mathrm{pH}$ insensitive. Ammonia stripping has been successfully used for largescale treatment of municipal wastewater treatment plants [64]. However, in practice, packed towers are easily fouled [61]. Therefore, Quan et al. [60] came up with a newly designed gas liquid contactor, a water-sparged aerocyclone (WSA). The contactor displayed higher stripping efficiency and excellent mass transfer efficiency and consumed less air compared to stripping tanks and packed towers. Another concern in ammonia stripping is the chemical demand, which consists of (i) alkali for raising the $\mathrm{pH}$ and then (ii) acid for lowering the $\mathrm{pH}$ post stripping. $\mathrm{CO}_{2}$ absorption using stripped ammonia can be used to adjust the pH. McLeod et al. [65••] came up with a novel scheme where ammonia-rich wastewater was used as an absorbent to selectively extract $\mathrm{CO}_{2}$ from biogas, during its upgrading to biomethane in a packed bed mode. The study claimed recovery of ammonia as $\mathrm{NH}_{4} \mathrm{HCO}_{3}$, which is a commercially profitable fertilizer. Jiang et al. [66] recovered $90 \%$ ammonia from anaerobically digested dairy manure as $\left(\mathrm{NH}_{4}\right)_{2} \mathrm{SO}_{4}$. The study suggested its use as concentrated nitrogen fertilizer. The scheme also produced electricity and biogas. Ledda et al. [67] used animal slurries to recover nitrogen as $\left(\mathrm{NH}_{4}\right)_{2} \mathrm{SO}_{4}$ from an integrated process scheme utilizing ultrafiltration, reverse osmosis, and cold ammonia stripping. The scheme recovered $71 \%$ nitrogen with $1.8 \mathrm{~m}^{3}$ concentrated $\left(\mathrm{NH}_{4}\right)_{2} \mathrm{SO}_{4}$ obtained for every $100 \mathrm{~m}^{3}$ of treated digestate.

\section{Membrane-Based Recovery Schemes}

Membrane-based separation processes have been utilized in many wastewater operations $[61,68-70]$ with microfiltration (MF), ultrafiltration (UF), nanofiltration (NF), and reverse osmosis (RO) being the predominant technologies. Nunes and 
Peimmann [69] recovered ammonia gas in an acid solution using a gas-permeable membrane operated by vacuum pressure. Hasanoglu et al. [70] recovered ammonia as $\left(\mathrm{NH}_{4}\right)_{2} \mathrm{SO}_{4}$ on the permeate side of a macroporous hydrophobic membrane. Kurama et al. [71] recovered $96.9 \%$ of ammonium ions from using RO. Gerardo et al. [72] using cross-flow MF recovered nitrogen and phosphorus from dairy farm sludge. Mondor et al. [73] produced a concentrated nitrogen fertilizer (containing $13 \mathrm{~g} / \mathrm{l}$ of $\mathrm{NH}_{3}-\mathrm{N}$ ) from liquid swine manure using electro-dialysis and reverse osmosis; however, they noticed significant $(21.2 \%)$ ammonia volatilization in the process. Membrane-based processes offer distinct advantages as ammonia recovery is independent of gas or liquid flow rates, absence of secondary pollutants in ammonia permeate, and concentration of ammonia does not affect ammonia removal efficiency.

A summation of all nitrogen removal and recovery methods, as discussed above, is provided in Table 1:

\section{Methods of Phosphorus Recovery}

\section{Physical Filtration and Membrane Processes}

In areas where phosphorus concentrations are close to the regulated effluent levels, rapid sand filtration can offer a simple and practical solution for tertiary phosphorus reduction. Phosphorus in wastewater can exist as both solid organics and as dissolved phosphates. Solid organic phosphates are directly related to the concentration of 5-day biochemical oxygen demand $\left(\mathrm{BOD}_{5}\right)$, total suspended solids (TSS), and volatile suspended solids (VSS) of the wastewater [74].

Performance evaluations performed by Barrett have shown that rapid sand filtration can remove, on average, $90 \%$ of TSS in wastewater, leading to an effluent concentration of $\sim 0.05 \mathrm{mg} \mathrm{P} / \mathrm{L}$ in the form of organic phosphates [75]. While rapid sand filtration could provide a viable option for solid organic phosphate removal in wastewater, it will not help in the reduction of dissolved phosphorus, nor will it provide an easy source of recoverable phosphorus.

An alternative to rapid sand filtration is membrane filtration, which has been gaining ground in recent years due to improvements in performance and cost. Unlike rapid sand filtration, membrane filtration has the added benefit of collecting dissolved as well as solid phosphorus, drastically improving phosphorus removal. Some of the more common membrane filters currently in use are tertiary membrane filters, reverse osmosis (RO) systems, and membrane bioreactors (MBRs), which use a suspended growth medium to aid in removal. Facilities using these systems have seen effluent concentrations of $\sim 0.04 \mathrm{mg} \mathrm{P} / \mathrm{L}$ for tertiary membranes and MBRs, and as low as $0.008 \mathrm{mg} \mathrm{P} / \mathrm{L}$ for RO systems [76]. Although these processes produce excellent results, they are often expensive and, like rapid sand filtration, do not provide an easily recoverable source of phosphorus.

Table 1 Summary of methods for nitrogen recovery

\begin{tabular}{|c|c|c|c|c|}
\hline Method & Process & Recovery results & Remarks & Ref. \\
\hline \multirow{4}{*}{$\begin{array}{l}\text { Ion exchange and } \\
\text { adsorption }\end{array}$} & $\mathrm{Na}^{+}$-activated natural zeolite & $98 \%$ recovery $\mathrm{NH}_{4} \mathrm{Cl}$ & Max uptake at $\mathrm{pH} 7$ & {$[26]$} \\
\hline & $\begin{array}{l}\text { Concerted } \mathrm{NH}_{4}^{+} \text {uptake and } \mathrm{PO}_{4}{ }^{3-} \\
\text { precipitation }\end{array}$ & $\begin{array}{l}\text { Precipitate- } \mathrm{NH}_{4}{ }^{+} \text {-loaded natural } \\
\text { zeolite }\end{array}$ & Uptake in $5 \mathrm{~min}$ & {$[17]$} \\
\hline & Palygorskite nanocomposite & Uptake of $237.7 \mathrm{mg} / \mathrm{g}$ & Uptake in $15 \mathrm{~min}$ & {$[37]$} \\
\hline & Resin prepared from wheat straw & $\begin{array}{l}\text { Simultaneous uptake of } \mathrm{NH}_{4}{ }^{+} \text {and } \\
\mathrm{PO}_{4}{ }^{3-} \text { ions }\end{array}$ & Excellent water retention & {$[40]$} \\
\hline \multirow[t]{3}{*}{$\begin{array}{l}\text { Bioelectrochemical } \\
\text { systems }\end{array}$} & $\begin{array}{l}\text { Microbial fuel cell (MFC) and cation } \\
\text { exchange membrane (CEM); } \\
\text { recovery from urine }\end{array}$ & $\mathrm{NH}_{3}(\mathrm{~g})$ recovery as $\left(\mathrm{NH}_{4}\right)_{2} \mathrm{SO}_{4}$ & Low energy; no alkali needed & {$[50 \bullet \bullet$} \\
\hline & $\begin{array}{l}\text { Recovery from anaerobic digester } \\
\text { microbial electrolysis cells (MECs) }\end{array}$ & $\mathrm{NH}_{3}(\mathrm{~g})$ stripped by produced $\mathrm{H}_{2}(\mathrm{~g})$ & Low energy demand & {$[51 \bullet \bullet]$} \\
\hline & Recovery from WW using MEC & $\begin{array}{l}\mathrm{H}_{2}(\mathrm{~g}) \text { produced and } \mathrm{NH}_{3} \text { recovery } \\
\quad(96 \%)\end{array}$ & Low energy & {$[53]$} \\
\hline \multirow[t]{2}{*}{$\begin{array}{l}\text { Ammonia } \\
\text { stripping }\end{array}$} & $\begin{array}{l}\text { Ammonia-rich } \mathrm{WW} \text { as absorbent to } \\
\text { extract } \mathrm{CO}_{2} \text { from biogas }\end{array}$ & Recovered as $\mathrm{NH}_{4} \mathrm{HCO}_{3}$ & $\begin{array}{l}\text { High commercial viability; } \\
\text { cleaner biogas fuel }\end{array}$ & {$[64]$} \\
\hline & $\begin{array}{l}\text { An integrated scheme involving } \\
\text { ultrafiltration, reverse osmosis (RO) } \\
\text { and cold stripping air stripping in } \\
\text { packed bed tower }\end{array}$ & $\begin{array}{l}71 \% \text { recovery as }\left(\mathrm{NH}_{4}\right)_{2} \mathrm{SO}_{4} 92 \% \\
\text { recovery }\end{array}$ & $\begin{array}{l}\text { Recycled clean water ( } 49 \% \text { of } \\
\text { initial volume); high } \\
\text { commercial viability process } \\
\text { optimized for } \mathrm{pH} \text { and } \\
\text { temperature }\end{array}$ & {$[57,62,66]$} \\
\hline \multirow[t]{2}{*}{$\begin{array}{l}\text { Membrane } \\
\text { separation }\end{array}$} & Macroporous hydrophobic membrane & $\begin{array}{l}\text { Recovered as }\left(\mathrm{NH}_{4}\right)_{2} \mathrm{SO}_{4} \text { on the } \\
\text { permeate side }\end{array}$ & $\begin{array}{l}99.83 \% \text { recovery; requires } \\
\text { ammonia volatilization }\end{array}$ & [69] \\
\hline & $\mathrm{RO}$ on liquid swine manure & $\begin{array}{l}\text { Recovered as conc. nitrogen fertilizer } \\
\quad\left(13 \mathrm{~g} / 1 \mathrm{NH}_{3}-\mathrm{N}\right)\end{array}$ & High $\mathrm{NH}_{3}$ volatilization $(21.2 \%)$ & {$[72]$} \\
\hline
\end{tabular}




\section{Chemical Precipitation}

In some cases, the easiest and cheapest way to remove excess dissolved phosphorus from wastewater effluent is through chemical precipitation, often through the use of calcium, aluminum, or iron. The most common precipitates used by wastewater treatment facilities are lime $\left(\mathrm{Ca}(\mathrm{OH})_{2}\right)$, alum $\left(\mathrm{Al}_{2}\left(\mathrm{SO}_{4}\right)_{3} \cdot 18 \mathrm{H}_{2} \mathrm{O}\right)$, and ferric chloride $\left(\mathrm{FeCl}_{3}\right)$ [77]. The use of these chemicals can also form trace amounts of soluble hydroxide and phosphate complexes, though the concentrations of these complexes are low enough that they should not interfere with precipitation.

Alkalinity, $\mathrm{pH}$, and hardness are major factors to consider when using chemical precipitation to remove phosphorus from wastewater. Iron phosphate and its oxyhydroxide complexes approach minimum solubility at $\mathrm{pH}$ ranges of 4.0-6.0, while aluminum phosphate and its oxyhydroxide complexes reach minimum solubility at a $\mathrm{pH}$ range of 5.0-7.0. Because of this, adjusting $\mathrm{pH}$ is generally not a major issue; however both processes consume alkalinity, so adjustments may be required depending on the source of the wastewater influent. Calcium apatite $\left(\mathrm{Ca}_{10}\left(\mathrm{PO}_{4}\right)_{6}(\mathrm{OH})_{2}\right)$ requires relatively high $\mathrm{pH}(>9.0)$ to reach minimum solubility, which requires softening of the wastewater through the formation of calcium carbonate $\left(\mathrm{CaCO}_{3}\right)$. The formation of $\mathrm{CaCO}_{3}$, coupled with the intended precipitation of calcium apatite, dramatically adds to the sludge production of the treatment facility [74]. In spite of this increase in sludge, experimental usage of calcium precipitation with wastewater effluent [78], anaerobic digester liquor [79], and synthetic waste streams [80, 81•] show phosphorus removal between 80 and $99 \%$, assuming elevated $\mathrm{pH}$ values are used.

While precipitation will reduce dissolved phosphorus, reuse and recovery of the phosphate from the sludge is impractical, unless tertiary infrastructure is in place to perform chemical reduction [6]. Precipitation without recovery also has the negative effect of drastically increasing the amount of sludge formed during primary and secondary treatment, especially when using lime- or alum-based precipitation [82]. Even when the majority of phosphorus has been precipitated out of solution, residual calcium, aluminum, and iron salts will continue to precipitate with hydroxide; estimates show that sludge volume after chemical precipitation can increase by as much as $35 \%$ [83].

One experimental attempt to recover calcium phosphate is the Geestmerambacht enhanced biological treatment process. Using a fluidized bed reactor, seed particles of silica are introduced to the effluent, collecting calcium phosphate and forming an easily extractable pellet. These pellets have relatively high phosphorus content (up to $11 \%$ as phosphorus), low water content (5-10\%), and low heavy-metal impurities; although they are not as concentrated as phosphate rock, they do provide a clean source of phosphorus. Experimental data, however, shows lower phosphorus loading than models would suggest, possibly due to interference from organic loading on the silica seeds [84].

In addition to calcium phosphate, many wastewater treatment plants have observed the natural formation of struvite, either in magnesium $\left(\mathrm{MgNH}_{4} \mathrm{PO}_{4}\right)$ or potassium $\left(\mathrm{KNH}_{4} \mathrm{PO}_{4}\right)$ form. This precipitate forms spontaneously at elevated $\mathrm{pH}$ levels $(>8.0)$ when equal parts dissolved phosphate, ammonium, and either magnesium or potassium enter a highly turbulent system, such as in the underground transfer pipe networks of treatment facilities. Struvite is problematic for certain forms of phosphorus production due to its ability to release ammonia gas and produce high nitrogen emission levels. However, struvite can be used as a form of high-grade slow-release fertilizer, which makes it ideal for preventing excessive phosphorus concentrations in runoff [6]. Struvite formation has the added benefit of not only reducing dissolved levels of phosphorus and nitrogen but also in reducing hardness caused by magnesium. In many cases, particularly those where animal and agricultural waste is the main source of $\mathrm{N}$ and $\mathrm{P}, \mathrm{Mg}$ must be supplemented into the system to promote crystallization. In recent years, struvite recovery has been implemented in the treatment of a variety of wastewater sources, including landfill leachate [85], anaerobic digester effluent [86], as well as swine $[87,88]$, poultry [89], and fertilizer wastewater [90•]. In all cases, after the introduction of $\mathrm{Mg}$, struvite recovery was shown to be between 85 and $97 \%$.

\section{High-Temperature Acid Hydrolysis}

As phosphorus accounts for approximately $2-3 \%$ of the organic solids in typical primary and secondary wastewater treatment sludge (higher if chemical precipitation is used), high-temperature acid hydrolysis and extraction of the phosphorus can be a viable option for some treatment facilities [91]. Research performed by Hultman has shown that normal wastewater treatment sludge that is dewatered, incinerated, and then digested in hydrochloric acid $(\mathrm{HCl})$ can release phosphorus in the usable form of phosphoric acid $\left(\mathrm{H}_{3} \mathrm{PO}_{4}\right)$ with up to $85 \%$ yield [ 92 ]. $\mathrm{H}_{3} \mathrm{PO}_{4}$ is a key element to modified solvent extraction processes, which are essential to the development of feedstock. Acid hydrolysis does have the added drawback of co-dissolving concentrated amounts of iron, aluminum, calcium, and heavy metals alongside the phosphorus; recent work with $\mathrm{pH}$ adjustments [93], sulfide precipitation [94], and cation exchange [95•] have helped reduce these contaminant levels.

Sludge treatment can also be used to collect phosphorus in alternative forms. The CAMBI/KREPRO ${ }^{\mathrm{TM}}$ process uses high-temperature acid hydrolysis to reduce sludge into iron phosphate and a concentrated sludge residue, which can be used as a fertilizer and biofuel, respectively. This process has proven successful in Helsingborg, Sweden, where a full-scale 
pilot system has proven to be capable of handling $500 \mathrm{~kg}$ $\mathrm{TS} / \mathrm{h}$ with a $75 \%$ recovery rate [92]. Additional work is also being done to react iron phosphate with iron sulfide to release soluble phosphates, which can then be used as a hybrid hydrolysis/precipitation process to form calcium phosphate or struvite. In some novel cases, the iron sulfide is being created on-site through sulfur-reducing microorganisms, allowing both the reduction of phosphorus and sulfur in the treated effluent [6].

\section{Biological Assimilation}

The use of constructed wetlands (CWs) for biological assimilation of excess nutrients is a fairly new concept, with Dr. Käthe Seidel conducting the first serious research into the design of efficient wetlands in 1953, and the first fullscale CW constructed in 1967 [96]. Since these first attempts, CWs have been used to treat a wide range of wastewaters, including effluent from domestic wastewaters, dairy farms, palm oil production, distilleries, natural rubber production, tanneries, textile manufacturing, electroplating, pulp and paper production, pesticide production, and heavy metal production [97].

Depending on location and the wastewater being treated, CWs can be categorized by their water level (free water surface or subsurface flow), the types of plants used (free-floating, floating-leaved, submerged, or emergent), and the flow direction (horizontal, vertical downflow, or vertical upflow). Nearly all CWs, however, use a combination of shallow water, low flow velocity, dense vegetation, and long, narrow channels to help create plug flow conditions to remove a wide variety of wastewater contaminants [98]. Suspended solids are removed through sedimentation, aggregation, and surface adhesion, while settleable organics are removed by deposition and filtration. Soluble organics are degraded aerobically and anaerobically by suspended microbial growth, and oxygen is added to the system through the air-water interface and the plant life present in the CWs [99]. Nitrogen is removed through nitrification/denitrification in aerobic and anaerobic zones; ammonia is oxidized in aerobic zones, and nitrate is converted to nitrogen gas and nitrous oxide in anoxic zones [100].

Phosphorus can be removed through microbial and vegetative assimilation, precipitation with di/trivalent cations in the soil/sediment, or adsorption onto clays and organic matter. Phosphorus can also be stored in peat accumulations. Subsurface CWs rarely precipitate or adsorb phosphorus due to the fact that the media used (crushed stone or pea gravel) is very low in iron, aluminum, and calcium, although high-sorption media such as steel slag and light weight clay aggregates do show promise for future CWs [101]. Microbial assimilation of phosphorus is often high, but it represents a short-term solution due to the high turnover rate of microbes in CWs [102]. The temperature-dependent nature of many of these species restricts their use to tropical and subtropical regions, however [103]. This restriction prevents the use of biological assimilation in cold climates, although pilot plants such as the Houghton Lake Project in Ann Arbor, MI have been tested to develop stronger CW systems [104].

Because of these issues, biological assimilation through plant and algae uptake is one of the only reliable long-term method for phosphorus removal in most CWs [102]. The most common species of vegetation used for free-surface assimilation are Eichhornia crassipes (water hyacinth), Pistia stratiotes (water lettuce), and several species of Lemnaceae (duckweed); these aquatic plants can be harvested and sold as a source of nutrients in fish and animal feeds, while also removing as much as $83-87 \%$ total nitrogen and $70-85 \%$ total phosphorus removal from the wastewater streams [105]. In some places such as Ghana, fish and other aquacultural methods are being introduced to CWs that have high algae content; in addition to the harvested plant matter, the fish themselves thrive on the high-nutrient algae and can be sold for a profit $[106 \bullet \bullet$. The conditions present in most CWs are also favorable for the controlled growth of algae that can be used to develop biofuels such as biodiesel, biomethane, and bioethanol [107•, 108•].

\section{Physical-Chemical Adsorption and Ion Exchange}

Physical-chemical adsorption offers many benefits over alternative phosphorus removal methods. Depending on the sorbent material, the attraction between sorbent and sorbate can be either physical or chemical; physical sorption generally uses van der Waals forces to attract the targeted solute, while chemical sorption removes the targeted solute through a chemical reaction [109].

Adsorption and ion exchange can be used either in the form of a fixed-bed column system through which wastewater is passed, or it can be dispersed throughout wastewater to be settled out in a downstream clarifier. Dispersal is best used when the sorbent material cannot be reused, if recovery of the solute is not necessary, or if increasing sludge volume is not a problem; powdered activated carbon is often used in this manner. When appropriate sorbents are used, fixed-bed column systems have several major advantages over other methods of phosphorus removal and recovery. Downstream from the column, the wastewater effluent contains non-detect or very low phosphorus concentrations until exhaustion of the sorbent is reached. Due to the physical nature of most commercial sorbents, there is also no additional sludge formed. The sorbent can also be regenerated and reused repeatedly, and phosphorus can be easily recovered from the regenerant in a usable form such as struvite [110]. Except for periodic cleaning, redirection of wastewater flow from exhaustion to 
regeneration, and the subsequent removal of phosphorus from regenerant, sorption is an entirely passive process that requires little to no maintenance while running. A pilot-scale version of this process, called the REM NUT ${ }^{\circledR}$ process, was tested in Massafra, Italy. The hybrid ion exchange/precipitation process was able to remove ammonium, potassium, and orthophosphates through the use of a mixed bed of cation and anion exchange resins. Regeneration was performed using a $0.06 \mathrm{M} \mathrm{NaCl}$ solution, and the removed nutrients were then precipitated out as struvite through the addition of magnesium [111].

Many different materials have been suggested as phosphorus adsorbents. Unfortunately, each material is subjected to limitations based on its own specific composition, which makes it difficult to determine common removal and regeneration efficiencies. Ferric and aluminum hydroxides are common adsorbents, due to their ability to form ligands with oxy-anions such as phosphates [112-114]. Recent research has also included phosphorus sorption onto fly ash [115], blast furnace slags [116], gas concrete [117], crushed oyster shell powder [118], alum sludge [119], active red mud [120], synthetic boehmites [121], and calcite [122].

Some common limitations to adsorption are the high cost of the regenerant solutions and the sorbents themselves, pretreatment of wastewater influent to function within the specific sorbent's capabilities, and the safe disposal of spent regenerant. Depending on the sorbent and regenerant used, these can be overcome through several means. Sorbents made from the waste products of other processes, like blast furnace slags and alum sludge, bring the cost of materials down. Precipitating phosphorus out of regenerant allows for the continued recycling and reuse of the solution. Using nonhazardous regenerant solutions, like seawater at a neutral $\mathrm{pH}$, also reduces the need for hazardous waste disposal $[30,110]$.

A summation of all phosphorus removal and recovery methods, as discussed above, is provided in Table 2:

Table 2 Summary of methods of phosphorous recovery

\begin{tabular}{|c|c|c|c|c|}
\hline Method & Process & Recovery results & Remarks & Ref. \\
\hline \multirow{3}{*}{$\begin{array}{l}\text { Physical filtration } \\
\text { and membrane } \\
\text { processes }\end{array}$} & Rapid sand filtration & $90 \%$ TSS removal & \multirow{3}{*}{$\begin{array}{l}\text { Good suspended P removal, but } \\
\text { minimal dissolved P removal }\end{array}$} & [74] \\
\hline & $\begin{array}{l}\text { Membrane filters } \\
\text { Membrane bioreactors }\end{array}$ & $\begin{array}{l}\mathrm{P} \text { reduction to trace amounts }(0.008- \\
0.04 \mathrm{mg} / \mathrm{L} \text { effluent } \mathrm{P}\end{array}$ & & {$[75]$} \\
\hline & Reverse osmosis & concentrations) & & \\
\hline \multirow[t]{3}{*}{$\begin{array}{l}\text { Chemical } \\
\text { precipitation }\end{array}$} & $\begin{array}{l}\text { Calcium, aluminum, and iron } \\
\text { precipitation }\end{array}$ & Dissolved P removal of $80-99 \%$ & $\begin{array}{l}\text { Requires alkalinity and } \mathrm{pH} \text { control, } \\
\text { and leads to increased sludge } \\
\text { production }\end{array}$ & $\begin{array}{l}{[6,73,76-80} \\
81 \bullet, 82]\end{array}$ \\
\hline & $\begin{array}{l}\text { Geestmerambacht enhanced } \\
\text { biological treatment process }\end{array}$ & $\begin{array}{l}\text { High P content }(\sim 11 \%) \text {, low water } \\
\quad \text { content }(5-10 \%) \text {, low impurities }\end{array}$ & $\begin{array}{l}\text { Low energy demand, no sludge } \\
\text { formation }\end{array}$ & {$[83]$} \\
\hline & Struvite & $\begin{array}{l}\text { Reduces dissolved } \mathrm{P} \text { to trace amounts, } \\
\text { struvite recovery } 85-97 \%\end{array}$ & $\begin{array}{l}\mathrm{Mg} \text { addition is required, } \\
\text { spontaneous formation, can be } \\
\text { used as high-grade fertilizer }\end{array}$ & {$[6,84-89]$} \\
\hline \multirow[t]{3}{*}{$\begin{array}{l}\text { Chemical reduction } \\
\text { and extraction }\end{array}$} & $\begin{array}{l}\mathrm{HCl} \text { digestion of WWTP } \\
\text { sludge }\end{array}$ & $\begin{array}{l}\text { Releases } \mathrm{P} \text { as phosphoric acid with } \\
\sim 85 \% \text { recoverability }\end{array}$ & $\begin{array}{l}\text { Produces key element for modified } \\
\text { solvent extraction }\end{array}$ & [91] \\
\hline & $\mathrm{CAMBI} / \mathrm{KREPRO}^{\mathrm{TM}}$ process & $\begin{array}{l}\text { reduction of WWTP sludge to iron } \\
\text { phosphate with } 75 \% \text { recovery }\end{array}$ & Produces iron phosphate fertilizer & [91] \\
\hline & $\begin{array}{l}\mathrm{pH} \text { adjustments, sulfide } \\
\text { precipitation, and cation } \\
\text { exchange supplementation }\end{array}$ & $\begin{array}{l}\text { Supplements other chemical reduction } \\
\text { techniques }\end{array}$ & $\begin{array}{l}\text { Reduces heavy metal contaminants } \\
\text { and buildup of } \mathrm{Fe}, \mathrm{Al} \text {, and } \mathrm{Ca} \text { ions }\end{array}$ & {$[6,92-94]$} \\
\hline $\begin{array}{l}\text { Biological } \\
\quad \text { assimilation }\end{array}$ & Constructed wetlands & $\begin{array}{c}\text { Combined nitrogen }(83-87 \%) \text { and } \\
\text { phosphorus }(70-85 \%) \text { removal }\end{array}$ & $\begin{array}{l}\text { Many alternative designs. Recovery } \\
\text { as fish/animal feeds, biofuels, } \\
\text { aquaculture }\end{array}$ & $\begin{array}{l}{[95 \bullet, 96,97} \\
99-105 \\
106 \bullet \bullet, 107 \bullet]\end{array}$ \\
\hline \multirow{9}{*}{$\begin{array}{l}\text { Physical-chemical } \\
\text { adsorption and ion } \\
\text { exchange }\end{array}$} & Fly ash & \multirow{9}{*}{$\begin{array}{l}\text { Wide variety of materials with wide } \\
\text { range of results, non-detect and } \\
\text { trace } \mathrm{P} \text { concentrations possible }\end{array}$} & \multirow{9}{*}{$\begin{array}{l}\text { No additional sludge formation, } \\
\text { regeneration allows for multiple } \\
\text { uses and easy P recovery, passive } \\
\text { systems, low maintenance }\end{array}$} & [114] \\
\hline & Blast furnace slags & & & [115] \\
\hline & Gas concrete & & & [116] \\
\hline & Crushed oyster shells & & & {$[117]$} \\
\hline & Alum sludge & & & [118] \\
\hline & Active red mud & & & [119] \\
\hline & Synthetic boehmites & & & {$[120]$} \\
\hline & Calcite & & & {$[121]$} \\
\hline & $\begin{array}{l}\text { Ferric and aluminum } \\
\text { hydroxides }\end{array}$ & & & {$[111-113]$} \\
\hline
\end{tabular}




\section{Conclusion}

Macronutrients nitrogen and phosphorus are essential for life on the earth. However, their removal from waste streams is also critical to mitigate the environmental problem of eutrophication of water-receiving bodies. A plethora of technologies exists that can achieve this goal; however, biological nitrification and de-nitrification and chemical precipitation are the most common processes used today to remove nitrogen and phosphorus, respectively. But both processes cannot achieve recovery of nitrogen or phosphorus. As readily extractable phosphorus deposits dwindle, and energy footprint plays an increasing role in nitrogenous fertilizer production, recovery of nitrogen and Phosphorus from waste stream is increasingly growing in importance. This practice is in alignment with a paradigm shift where the waste stream is not just to be looked upon as a cost item (to remove pollutants from it in order that environmental regulations are met) but as a carrier of extractable resources.

This paper presents an exhaustive review of processing technologies that can meet the goal of recovering Nitrogen and Phosphorus from a waste stream. Future research is needed to combine fundamental understanding with adaptation of technology for particular site/wastewater.

\section{References}

Papers of particular interest, published recently, have been highlighted as:

- Of importance

• Of major importance

1. Tornroth-Horsefield S, Neutze R. Opening and closing the metabolite gate. Proc Natl Acad Sci U S A. 2008;105(50): 19565-6.

2. B (Science Advisory Board to the EPA). Reactive nitrogen in the United States; an analysis of inputs, flows, consequences, and management options. Washington, DC: US EPA; 2011.

3. Fields S. Global nitrogen: cycling out of control. Environ Health Perspect. 2004;112(10):A556.

4. United Nations. Country population statistics and projections 1950-2050, report, Food and Agric. Org. of the U. N., Rome; 1996.

5. Galloway JN, Dentener FJ, Capone DG, Boyer EW, Howarth RW, Seitzinger SP, et al. Nitrogen cycles: past, present, and future. Biogeochemistry. 2004;70(2):153-226.

6. Duley B. Recycling phosphorus by recovery from sewage. Brussels, Belgium: Centre Europeen d'Etudes des Polyphosphates, Natural History Museum; 1998. p. 1-17.

7. The Phosphate File. Centre Europeen d'Etudes des Polyphosphates. Brussels, Belgium: Natural History Museum; 1997. p. 1-14.

8. Smil V. Nitrogen and food production: proteins for human diets. AMBIO: J Human Environ. 2002;31(2):126-31.
9. Pinder RW, Bettez ND, Bonan GB, Greaver TL, Wieder WR, Schlesinger WH, et al. Impacts of human alteration of the nitrogen cycle in the US on radiative forcing. Biogeochemistry. 2013;114(1-3):25-40.

10. Muller NZ, Mendelsohn R. Measuring the damages of air pollution in the United States. J Environ Econ Manag. 2007;54(1):1-14.

11. Robertson GP, Bruulsema TW, Gehl RJ, Kanter D, Mauzerall DL, Rotz CA, et al. Nitrogen-climate interactions in US agriculture. Biogeochemistry. 2013;114(1-3):41-70.

12. Litke D. Review of phosphorus control measures in the United States and their effects on water quality. Denver, CO: United States Geological Survey; 1999.

13. Sharpley AN, Daniel T, Sims T, Lemunyon J, Stevens R, Parry R. Agricultural Phosphorus and Eutrophication. 2nd ed. Agricultural Research Service: United States Department of Agriculture; 2003.

14. Otoo M, Drechsel P. Resource Recovery from Waste: Business Models for Energy, Nutrient and Water Reuse. 2015.

15. Sprynskyy M, Lebedynets M, Zbytniewski R, Namieśnik J, Buszewski B. Ammonium removal from aqueous solution by natural zeolite, Transcarpathian mordenite, kinetics, equilibrium and column tests. Sep Purif Technol. 2005;46(3):155-60.

16. Eriksson E, Auffarth K, Henze M, Ledin A. Characteristics of grey wastewater. Urban Water. 2002;4(1):85-104.

17. Karapinar N. Application of natural zeolite for phosphorus and ammonium removal from aqueous solutions. J Hazard Mater. 2009;170(2):1186-91.

18. Widiastuti N, Wu H, Ang HM, Zhang D. Removal of ammonium from greywater using natural zeolite. Desalination. 2011;277(1): $15-23$.

19. Sarioglu M. Removal of ammonium from municipal wastewater using natural Turkish (Dogantepe) zeolite. Sep Purif Technol. 2005;41(1):1-11.

20. Malovanyy A, Sakalova H, Yatchyshyn Y, Plaza E, Malovanyy $\mathrm{M}$. Concentration of ammonium from municipal wastewater using ion exchange process. Desalination. 2013;329:93-102.

21. Du Q, Liu S, Cao Z, Wang Y. Ammonia removal from aqueous solution using natural Chinese clinoptilolite. Sep Purif Technol. 2005;44(3):229-34.

22. Englert AH, Rubio J. Characterization and environmental application of a Chilean natural zeolite. Int J Miner Process. 2005;75(1):21-9.

23. Li M, Zhu X, Zhu F, Ren G, Cao G, Song L. Application of modified zeolite for ammonium removal from drinking water. Desalination. 2011;271(1):295-300. This paper presents a comprehensive modification methodology for natural zeolites using $\mathrm{NaCl}$ treatment, mixing with Sodium SIlicate and Activated Carbon, subsequent extrusion and calcination to prepare a modified zeolite.

24. Tsitsishvili GV. Natural zeolites. Ellis Horwood; 1992.

25. Leyva-Ramos R, Monsivais-Rocha JE, Aragon-Piña A, BerberMendoza MS, Guerrero-Coronado RM, Alonso-Davila P, et al. Removal of ammonium from aqueous solution by ion exchange on natural and modified chabazite. J Environ Manag. 2010;91(12):2662-8.

26. Alshameri A, Ibrahim A, Assabri AM, Lei X, Wang H, Yan C. The investigation into the ammonium removal performance of Yemeni natural zeolite: modification, ion exchange mechanism, and thermodynamics. Powder Technol. 2014;258:20-31.

27. Green M, Mels A, Lahav O. Biological-ion exchange process for ammonium removal from secondary effluent. Water Sci Technol. 1996;34(1):449-58.

28. Lahav O, Green M. Ammonium removal using ion exchange and biological regeneration. Water Res. 1998;32(7):2019-28.

29. Liberti L, Boari G, Passino R. Advanced wastewater treatment by ion exchange. Effluent Water Treat J. 1982; 22(7) 
30. Liberti L, Boari G, Petruzzelli D, Passino R. Nutrient removal and recovery from wastewater by ion exchange. Water Res. 1981;15(3):337-42.

31. Liberti L, Petruzzelli D, De Florio L. REM NUT ion exchange plus struvite precipitation process. Environ Technol. 2001;22(11): 1313-24.

32. Lind BB, Ban Z, Bydén S. Nutrient recovery from human urine by struvite crystallization with ammonia adsorption on zeolite and wollastonite. Bioresour Technol. 2000;73(2):169-74.

33. Lin L, Wan C, Lee DJ, Lei Z, Liu X. Ammonium assists orthophosphate removal from high-strength wastewaters by natural zeolite. Sep Purif Technol. 2014;133:351-6.

34. Huang H, Xiao D, Pang R, Han C, Ding L. Simultaneous removal of nutrients from simulated swine wastewater by adsorption of modified zeolite combined with struvite crystallization. Chem Eng J. 2014;256:431-8. This work simultaneously recovers Nitropgen and Phosphorus as struvite from swine wastewater using a modified zeolite.

35. Moradi O, Yari M, Zare K, Mirza B, Najafi F. Carbon nanotubes: a review of chemistry principles and reactions. Fullerenes, Nanotubes Carbon Nanostruct. 2012;20(2):138-51.

36. Zheng Y, Liu Y, Wang A. Fast removal of ammonium ion using a hydrogel optimized with response surface methodology. Chem Eng J. 2011;171(3):1201-8.

37. Maranon E, Ulmanu M, Fernandez Y, Anger I, Castrillón L. Removal of ammonium from aqueous solutions with volcanic tuff. J Hazard Mater. 2006;137(3):1402-9.

38. Wang X, Lü S, Gao C, Xu X, Zhang X, Bai X, et al. Highly efficient adsorption of ammonium onto palygorskite nanocomposite and evaluation of its recovery as a multifunctional slow-release fertilizer. Chem Eng J. 2014;252:404-14.

39. Zheng Y, Zhang J, Wang A. Fast removal of ammonium nitrogen from aqueous solution using chitosan-g-poly (acrylic acid)/ attapulgite composite. Chem Eng J. 2009;155(1):215-22.

40. Ma Z, Li Q, Yue Q, Gao B, Li W, Xu X, et al. Adsorption removal of ammonium and phosphate from water by fertilizer controlled release agent prepared from wheat straw. Chem Eng J. 2011;171(3):1209-17.

41. Liu J, Su Y, Li Q, Yue Q, Gao B. Preparation of wheat straw based superabsorbent resins and their applications as adsorbents for ammonium and phosphate removal. Bioresour Technol. 2013;143: $32-9$

42. Jellali S, Wahab MA, Anane M, Riahi K, Jedidi N. Biosorption characteristics of ammonium from aqueous solutions onto Posidonia oceanica (L.) fibers. Desalination. 2011;270(1):40-9.

43. Wahab MA, Jellali S, Jedidi N. Ammonium biosorption onto sawdust: FTIR analysis, kinetics and adsorption isotherms modeling. Bioresour Technol. 2010;101(14):5070-5.

44. Madigan MT, Martinko JM, Parker J. Brock biology of microorganisms. 9th ed. Upper Saddle River, NJ: Prentice Hall; 2000.

45. Heijne AT, Liu F, Weijden RVD, Weijma J, Buisman CJ, Hamelers HV. Copper recovery combined with electricity production in a microbial fuel cell. Environ Sci Technol. 2010;44(11):4376-81.

46. Logan BE, Call D, Cheng S, Hamelers HV, Sleutels TH, Jeremiasse AW, et al. Microbial electrolysis cells for high yield hydrogen gas production from organic matter. Environ Sci Technol. 2008;42(23):8630-40.

47. Liu H, Grot S, Logan BE. Electrochemically assisted microbial production of hydrogen from acetate. Environ Sci Technol. 2005;39(11):4317-20.

48. Logan BE, Hamelers B, Rozendal R, Schröder U, Keller J, Freguia S, et al. Microbial fuel cells: methodology and technology. Environ Sci Technol. 2006;40(17):5181-92.
49. Arends J, Verstraete W. 100 years of microbial electricity production: three concepts for the future. Microb Biotechnol. 2012;5(3): 333-46.

50.• Kuntke P, Geleji M, Bruning H, Zeeman G, Hamelers HVM, Buisman CJN. Effects of ammonium concentration and charge exchange on ammonium recovery from high strength wastewater using a microbial fuel cell. Bioresour Technol. 2011;102(6):4376-82. This work demonstrates combined ammonia recovery and energy production using a microbial fuel cell. If certain parameters are studied and optimized, this work can go a long way in the scheme implementation.

51.• Kuntke P, Smiech KM, Bruning H, Zeeman G, Saakes M, Sleutels THJA, et al. Ammonium recovery and energy production from urine by a microbial fuel cell. Water Res. 2012;46(8):2627-36. This work demonstrates combined ammonia recovery and energy production using a microbial fuel cell. If certain parameters are studied and optimized, this work can go a long way in the scheme implementation.

52. Desloover J, Abate Woldeyohannis A, Verstraete W, Boon N, Rabaey K. Electrochemical resource recovery from digestate to prevent ammonia toxicity during anaerobic digestion. Environ Sci Technol. 2012;46(21):12209-16.

53. Haddadi S, Elbeshbishy E, Lee HS. Implication of diffusion and significance of anodic $\mathrm{pH}$ in nitrogen-recovering microbial electrochemical cells. Bioresour Technol. 2013;142:562-9.

54. Wu X, Modin O. Ammonium recovery from reject water combined with hydrogen production in a bioelectrochemical reactor. Bioresour Technol. 2013;146:530-6.

55. Sleutels TH, Ter Heijne A, Buisman CJ, Hamelers HV. Steadystate performance and chemical efficiency of microbial electrolysis cells. Int J Hydrogen Energy. 2013;38(18):7201-8.

56. Janicek A, Fan Y, Liu H. Design of microbial fuel cells for practical application: a review and analysis of scale-up studies. Biofuels. 2014;5(1):79-92.

57. Ozturk I, Altinbas M, Koyuncu I, Arikan O, Gomec-Yangin C. Advanced physico-chemical treatment experiences on young municipal landfill leachates. Waste Manag. 2003;23(5):441-6.

58. Gustin S, Marinsek-Logarb R. Effect of $\mathrm{pH}$, temperature and air flow rate on the continuous ammonia stripping of the anaerobic digestion effluent. Process Saf Environ Prot. 2011;89:61-6.

59. Guo JS, Abbas AA, Chen YP, Liu ZP, Fang F, Chen P. Treatment of landfill leachate using a combined stripping, Fenton, SBR, and coagulation process. J Hazard Mater. 2010;178(1):699-705.

60. Quan X, Wang F, Zhao Q, Zhao T, Xiang J. Air stripping of ammonia in a water-sparged aerocyclone reactor. J Hazard Mater. 2009;170(2):983-8.

61. Norddahl B, Christensen KV, Horn V, Larsson M, duPreez JH. A membrane contactor for ammonia stripping, pilot scale experience and modeling. Desalination. 2006;199:172-4.

62. Bonmat1 A, Flotats X. Air stripping of ammonia from pig slurry: characterisation and feasibility as a pre-or post-treatment to mesophilic anaerobic digestion. Waste Manag. 2003;23(3):261-72.

63. Katehis D, Diyamandoglu V, Fillos J. Stripping and recovery of ammonia from centrate of anaerobically digested biosolids at elevated temperatures. Water Environ Res. 1998;70(2):231-40.

64. Zeng L, Li X, Liu J, Jenson E. Feasibility study of air stripping of ammonia from digested cattle manure. ADSW 2005 conference proceedings. 2005. pp. 656-663

65.• McLeod A, Jefferson B, McAdam EJ. Biogas upgrading by chemical absorption using ammonia rich absorbents derived from wastewater. Water Res. 2014;67:175-86. This paper desecribes a novel scheme where ammonia rich wastewater is used as an absorbent to selectively extract $\mathrm{CO}_{2}$ from biogas in a packed 
bed mode as $\mathrm{NH}_{4} \mathrm{HCO}_{3}$, which is a commercially profitable fertilizer.

66. Jiang A, Zhang T, Zhao QB, Li X, Chen S, Frear CS. Evaluation of an integrated ammonia stripping, recovery, and biogas scrubbing system for use with anaerobically digested dairy manure. Biosyst Eng. 2014;119:117-26.

67. Ledda C, Schievano A, Salati S, Adani F. Nitrogen and water recovery from animal slurries by a new integrated ultrafiltration, reverse osmosis and cold stripping process: A case study. Water Res. 2013;47(16):6157-66.

68. Masse L, Masse DI, Pellerin Y. The use of membranes for the treatment of manure: a critical literature review. Biosyst Eng. 2007;98(4):371-80.

69. Nunes SP, Peinemann KV. Membrane Technology. Wiley-VCH. 2001.

70. Hasanoğlu A, Romero J, Pérez B, Plaza A. Ammonia removal from wastewater streams through membrane contactors: Experimental and theoretical analysis of operation parameters and configuration. Chem Eng J. 2010;160(2):530-7.

71. Kurama H, Poetzschke J, Haseneder R. The application of membrane filtration for the removal of ammonium ions from potable water. Water Res. 2002;36(11):2905-9.

72. Gerardo ML, Zacharof MP, Lovitt RW. Strategies for the recovery of nutrients and metals from anaerobically digested dairy farm sludge using cross-flow microfiltration. Water Res. 2013;47(14): 4833-42.

73. Mondor M, Masse L, Ippersiel D, Lamarche F, Masse DI. Use of electrodialysis and reverse osmosis for the recovery and concentration of ammonia from swine manure. Bioresour Technol. 2008;99(15):7363-8.

74. Sedlak R. Phosphorus and nitrogen removal from municipal wastewater. New York: Lewis Publishers; 1991.

75. Barrett ME. Evaluation of sand filter performance. Center for Research in Water Resources, University of Texas at Austin. 2010.

76. Reardon R. Technical introduction of membrane separation processes for low TP limits. Session P3 of Water Environment Research Foundation (WERF) workshop 05-CTS-1W. March 911, 2006, Washington, D. C. 2006.

77. De-Bashan L, Bashan Y. Recent advances in removing phosphorus from wastewater and its future use as fertilizer (1997-2003). Water Res. 2004;38:4222-46.

78. Berg U, Donnert D, Weidler P, Kaschka E, Knoll G, Nuesch R. Phosphorus removal and recovery from wastewater by tobermorite-seeded crystallization of calcium phosphate. Wastewater Treat. 2006;52:131-8.

79. Okano K, Uemoto M, Kagami J, Miura K, Aketo TM, Toda M, et al. Novel technique for phosphorus recovery from aqueous solutions using amorphous calcium silicate hydrates (A-CSHs). Water Res. 2013;47:2251-9.

80. Oladoja N, Ololade I, Adesina A, Adelagun R, Sani Y. Appraisal of gastropod shell as calcium ion source for phosphate removal and recovery in calcium phosphate minerals crystallization procedure. Chem Eng Res Des. 2013;91:810-8.

81. Qiu L, Wang G, Zhang S, Yang Z, Li Y. An approach for phosphate removal with quartz sand, ceramsite, blast furnace slag and steel slag as seed crystal. Water Sci Technol. 2012;65:1048-53. This paper provides a novel procedure using common waste materials to achieve high percentage phosphate removal via calcium precipitation from synthetic wastewater.

82. Tchobanoglous G, Burton FL, Stensel HD. Metcalf \& Eddy, Inc.'s Wastewater Engineering: Treatment, Disposal, and Reuse, 4th Edition. New York: McGraw Hill, Inc; 2003. 1819.

83. Schmidtke NW. Sludge generation, handling and disposal at phosphorus control facilities. Ann Arbor, Michigan: Ann Arbor Science Publishers, Inc.; 1980.
84. Seckler MM, Bruinsma OSL, Van Rosmalen GM. Calcium phosphate precipitation in a fluidised bed in relation to process conditions: a black box approach. Water Res. 1996;30(7):1677-85.

85. Li X, Zhao Q, Hao X. Ammonium removal from landfill leachage by chemical precipitation. Waste Manage. 1999;19:409-15.

86. Uysal A, Yilmazel Y, Demirer G. The determination of fertilizer quality of FHT reformed struvite from effluent of a sewage sludge anaerobic digester. J Hazard Mater. 2010;181:248-54.

87. Nelson N, Mikkelson R, Hesterberg D. Struvite precipitation in anaerobic swine lagoon liquid: effect of $\mathrm{pH}$ and $\mathrm{Mg}: \mathrm{P}$ ratio and determination of rate constant. Bioresour Technol. 2003;89:229-36.

88. Song Y, Yuan P, Zheng B, Peng J, Yuan F, Gao Y. Nutrients removal and recovery by crystallization of magnesium ammonium phosphate from synthetic swine wastewater. Chemosphere. 2007;69:319-24.

89. Yilmazel Y, Demirer G. Removal and recovery of nutrients as struvite from anaerobic digestion residues of poultry manure. Environ Technol. 2011;32:783-94.

90. Hutnik N, Kozik A, Mazienczuk A, Piotrowski K, Wierbowska B, Matynia A. Phosphates (V) recovery from phosphorus mineral fertilizers industry wastewater by continuous struvite reaction crystallization process. Water Res. 2013;47:3635-43. This paper shows high phosphorus removal and recovery through struvite formation.

91. Strom PF. Invited Presentation for Water Quality Trading, 91st Annual Meeting. New Jersey: NJWEA, Atlantic City; 2006. Phosphorus removal techniques.

92. Hultman B. Phosphorus recovery from sewage sludges: research and experiences in Nordic countries. SCOPE 41 Newsletter (CEEP Publication), 29-33. 2001.

93. Takahashi M, Kato S, Shima H, Sarai E, Ichioka T, Hatyakawa S, et al. Technology for recovering phosphorus from incinerated wastewater treatment sludge. Chemosphere. 2001;44:23-9.

94. Franz M. Phosphate fertilizer from sewage sludge ash (SSA). Waste Manage. 2008;28:1809-18.

95. Donatello S, Tong D, Cheeseman C. Production of technical grade phosphoric acid from incinerator sewage sludge ash (ISSA). Waste Manage. 2010;30:1634-42. This research modifies existing high-temperature acid hydrolysis using cation exchange to reduce heavy metal contamination during the creation of phosphoric acid.

96. Vymazal J. Constructed wetlands for wastewater treatment. Water. 2010;2(3):530-49.

97. Abassi SA. Aquatic plants based water treatment systems in Asia. In: Reddy KR, Smith WH, editors. Aquatic plants for water treatment and resource recovery. Orlando, Florida: Magnolia Publishing; 1987. p. 175-98.

98. Reed SC, Middlebrooks EJ, Crites RW. Natural systems for waste management and treatment (1st ed.). New York: McGraw-Hill Book Company; 1988.

99. QDNR. Guidelines for using freewater surface constructed wetlands to treat municipal sewage. Queensland Department of Natural Resources. Australia: Brisbane; 2000.

100. Kadlec RH, Knight RL. Treatment wetlands. Boca Raton, Florida: CRC Press/Lewis Publishers; 1996.

101. Vymazal J, Kröpfelová L. Wastewater treatment in constructed wetlands with horizontal subsurface flow. Environ Pollut. 2008;14:203-322.

102. Reddy KR, Sacco PD. Decomposition of water hyacinth in agricultural drainage water. J Environ Qual. 1981;10:228-34.

103. Brix H, Schierup H. The use of aquatic macrophytes in water pollution control. Ambio. 1989;18:100-7.

104. Kadlec RH, Tilton DL. The use of freshwater wetlands as a tertiary wastewater treatment alternative. CRC Crit Rev Environ Control. 1979;9:185-212. 
105. Ozengin N, Elmaci A. Performance of duckweed (lemna minor L.) on different types of wastewater treatment. J Environ Biol. 2007;28(2):307-14.

106.• Otoo M, Dreschel P. Resource recovery from waste: business models for energy, nutrient and water reuse. IWMI and Earthscan (in press). 2015. This is a very thorough reference text discussing many different phosphorus and nitrogen removal and recovery methods.

107. Rawat I, Kumar R, Mutanda T, Bux F. Dual role of microalgae: phycoremediation of domestic wastewater and biomass production or sustainable biofuels production. Appl Energy. 2010;88: 3411-24. These papers use concepts taken from constructed wetland research to create biofuels from highnutrient wastewater.

108. Liu D, Wu X, Chang J, Gu B, Min Y, Ge Y, et al. Constructed wetlands as biofuel production systems. Nat Clim Chang. 2012;2: 190-4. These papers use concepts taken from constructed wetland research to create biofuels from highnutrient wastewater.

109. Reynolds TD, Richards PA. Unit operations and processes in environmental engineering (2nd ed.). Boston, Massachusetts: PWS Publishing Co; 1996.

110. Sengupta S, Pandit A. Selective removal of phosphorus from wastewater combined with its recovery as a solid-phase fertilizer. Water Res. 2011;45(11):3318-30.

111. Petruzzelli D, Dell'Erba A, Liberti L, Notarnicola M, SenGupta A. A phosphate-selective sorbent for the REM NUT process: field experience at Massafra wastewater treatment plant. React Funct Polym. 2004;60:195-202.
112. Barber TM. Phosphate adsorption by mixed and reduced iron phases in static and dynamic systems. (Doctoral dissertation, Stanford University, Stanford, California). 2002.

113. Sperlich A. Phosphate adsorption onto granular ferric hydroxide (GFH) for wastewater reuse. (Doctoral dissertation, Institut für Technischen Umweltschutz, Berlin, Germany). 2010.

114. Guan XH, Chen GH, Shang C. Adsorption behavior of condensed phosphate on aluminum hydroxide. J Environ Sci. 2007;19(3):312-8.

115. Ugurlu A, Salman B. Phosphorus removal by fly ash. Environ Int. 1998;24(8):911-8.

116. Johansson L, Gustafsson JP. Phosphate removal using blast furnace slags and opoka-mechanisms. Water Res. 2000. 259-265.

117. Oguz E, Gurses A, Campolat N. Removal of phosphate from wastewaters. Cement Concrete Res. 2003; 1109-13.

118. Namasivayam C, Sakoda A, Suzuki M. Removal of phosphate by adsorption onto oyster shell powder-kinetic studies. J Chem Technol Biotechnol. 2004;80(3):356-8.

119. Yang Y, Zhao YQ, Babatunde AO, Wang L, Ren YX, Han Y. Characteristics and mechanisms of phosphate adsorption on dewatered alum sludge. Sep Purif Technol. 2006;51(2):193-200.

120. Liu CJ, Li YZ, Luan ZK, Chen ZY, Zhang ZG, Jia ZP. Adsorption removal of phosphate from aqueous solution by active red mud. J Environ Sci. 2007;19(10):1166-70.

121. Yujiro W, Hirohisa Y, Takeshi K, Junzo T, Yu K, Yusuke M. Adsorption behavior of phosphorus on synthetic boehmites. In: Proceedings of the 19th International Japan-Korea Seminar on Ceramics; 2002. pp. 80-84.

122. Karageorgiou K, Paschalis M, Anastassakis GN. Removal of phosphate species from solution by adsorption onto calcite used natural adsorbent. J Hazardous Mater. 2007;139(3):447-52. 